\title{
Middle Adults' Housing Expectations for Old-age: A Study of Urban Area of Greater Kuala Lumpur
}

\author{
Ainoriza Mohd Aini*, Wan Nor Azriyati Wan Abd Aziz² and Nurul Farahana Zulkifli ${ }^{3}$ \\ 1,2,3 Centre for Sustainable Urban Planning \& Real Estate (SUPRE), Faculty of Built \\ Environment, University of Malaya, 50603 Kuala Lumpur, Malaysia. \\ *ainoriza@um.edu.my
}

\begin{abstract}
As Malaysia is becoming an ageing nation, it is important to examine the housing needs of the retiring age group in order to provide adequate retirement housing. The study examines the middle adults' housing expectation which will affect their housing preferences and decisions upon retirement. A face-to-face survey was conducted on 464 respondents aged 40 and above living in the urban concentrated areas of Greater Kuala Lumpur. Most of the respondents indicated that they have a strong willingness to continue to stay in their current homes and their opinions on the satisfaction level of comfort were evaluated in this survey. Though certain groups have their own preferences for their future housing plan, the findings revealed that most of the middle age adults have strong desire to age in place, surrounded by family members, friends as well as suitable facilities. This suggests that to a certain degree, the current housing will not be their desired retirement home. It is recommended that the housing policy should integrate the expectation and needs of the ageing population of the nation.
\end{abstract}

Keywords: Ageing population, Housing, Housing needs, Elderly, Malaysia

\section{INTRODUCTION}

Malaysia's population is ageing and is forecasted to become an aged nation by 2030 when 15 percent of the population will be classified as elderly. The ageing phenomenon occurred as a result of a rapid increase in the elderly population within the community, thus creating a global phenomenon that requires intensive supervision from numerous parties. Rapid development has transformed the mainly rural agricultural society to an increasingly urbanised industrial society. The changes in the economic development, migration and changes in the family structure have weakened the family support and care for older persons $(\mathrm{Ng}$ et al., 2012). The effects of modernisation and the pressure of the rat race in the workplace have resulted in many adults having to place their parents in institutional care. Currently, this is no longer viewed as being un-filial in some Asian society (Tang et al., 2009). This phenomenon has contributed to the increasing number of older persons who are living alone or in a nursing home. As such, the time has come to recognise a number of essential realities in relation to old age which include the changes in attitude towards old age, Malaysian elderly continue to live longer, have their own financial means, and live independently from their children. With the fast changing lifestyles, it is not just that the housing market that needs to reflect the requirement of the elderly community but also to match their aspirations.

This study focuses on Malaysian middle adults' housing satisfaction and expectation for their old age. In particular, the study looks into Malaysians living in urban areas of Greater Kuala Lumpur. The study was initially based on the assumption from previous research (Kwon et al., 2015; Ferreira, 2013; Hillcoat \& Ogg, 2013; Wardrip, 2010; Windley, 2003; Burby \& Rohe, 1990) that claimed residential satisfaction is highly associated with thedecision to remain in the current dwelling. As such, three key research questions were addressed in the study. Firstly, to what is the level of satisfaction of the middle adults regarding their current housing; secondly, what are the expected housing characteristics required by the middle adult population? Thirdly, what are their housing plans for the future?

In the context of this study, residential satisfactions are based on the respondents' expectations and they are are divided into two main categories: housing unit and neighbourhood. This paper is divided into several parts: the literature review and 
background section reviews past literature about the elderly housing options and elderly housing. Research methodology section describes the methodology adopted. The final section analyses the results and provides discussion on the implications of the findings.

\section{BACKGROUND AND LITERATURE REVIEW}

\subsection{Literature review}

Table 1 Population (Elderly) Projection 2040 ('000)

\begin{tabular}{lrrrrrr}
\hline Age & \multicolumn{7}{c}{ Year } \\
\hline $60-64$ & 2016 & 2020 & 2025 & 2030 & 2035 & 2040 \\
$65-69$ & 1041.6 & $1,306.30$ & $1,539.50$ & $1,735.10$ & $1,939.60$ & $2,218.90$ \\
$70-74$ & 785.6 & 958.4 & $1,222.90$ & $1,449.20$ & $1,644.70$ & $1,851.10$ \\
$75-79$ & 490.7 & 694 & 879.2 & $1,132.30$ & $1,355.10$ & $1,554.40$ \\
$80+$ & 331.1 & 405.9 & 600.1 & 770.1 & $1,006.10$ & $1,221.60$ \\
Total of elderly & 306.8 & 384.4 & 505.6 & 731.7 & $1,011.10$ & $1,384.70$ \\
$\begin{array}{l}\text { Total population } \\
\text { \% Elderly of }\end{array}$ & $31,660.70$ & $33,782.40$ & $36,022.70$ & $38,062.20$ & $39,879.30$ & $41,503.10$ \\
population & & & & & & $17 \%$ \\
\hline
\end{tabular}

Source: Statistics Department (2017)
Urbanization is a reality that could no longer be denied; it has impacted the elderly population around the world. The urbanization leads to different opportunities for its residents who are more exposed to the great social support facilities as well as stable financial support. This has given them the options to a wide range of public services, including health and social care expenditure and most importantly, the provision of suitable housing and living environment appropriate for senior citizens (Harding, 2008).

Housing is a basic human right, and it is widely known that the physical environment, location as well as the design has a significant impact not only on its occupant but also towards the community as a whole (Wagner, 2010). Housing must fulfil the needs for the daily activities of the ageing people and provide them with the feeling of satisfaction, security, comfort and independence. House can be viewed in 3 different perspectives, namely; physical, social as well as the personal (Tanner et al., 2008). Physically, it refers to the space that can be measured and is shaped by its function, culture and history. For instance, by providing security and shelter, housing fulfils
Malaysia is progressively becoming an ageing nation together with other countries due to advancement in health, economic and social aspect which consequently improves the quality of living for the elderly. According to the National Policy for Older Person 2011, Malaysia has earmarked the age of 60 as the starting age for the elderly. Table 1 shows the percentage projection of 60 years and above in Malaysia:

\section{Source: Statistics Department (2017)}

the physical needs of a person. This physical condition includes being strategically located nearby relevant services, hospitals, transportation and stores. Socially, it mainly encompasses the relationships with significant others such as family, friends as well as others who may enter the house on any occasion. Additionally, by providing a gathering and communal area, the housing fulfils the social needs of a person. Being a place where one can have a personal control and a place of selfexpression, makes a house a central locus in a person's life as it provides the occupants with the feeling of belonging, security, familiarity as well as freedom (Tanner et al., 2008).

Furthermore, if a house is inadequate for the needs of people living in it, it will never become a house in the first place (Demirkan, 2007). Underpinning this, the elderly who have diversified backgrounds which represent their present condition have unique housing needs compared to other age group population. Wagner (2010) stated that it is a common scenario that, what the elderly wants and need often become a neglected area of research inquiry. The demands for accessible housing are often determined by market conditions, 
government policies, and a variety of household and personal characteristics rather than by the needs and desires of the residents. In the Malaysian context, the housing needs of the ageing population are relatively neglected. Currently, limited researchhave been conducted to address the housing needs of the ageing population. A few of Malaysia's policy mention the housing needs of the ageing population, the need to provide facilities or perhaps, to assist in monetary form. However, there is a lack of a structured action plan undertaken by the government in meeting the housing needs of the ageing population.

For the elderly population, a house is often the central focus of their days. The studies on housing are vital as it is considered not just a shelter for the elderly community, but also a place for them to enhance the quality and the standards of living. Essentially, every human being has the right to own a house, and for the elderly, a house is considered a major factor in encouraging them to live dynamically. Thus, this makes it even more important to know and understand the housing needs as well as the personal and environmental predictors of housing satisfaction of the ageing population (Rioux, 2011). It is difficult to assume that the elderly have the same needs in housing. Assessing their condition thoroughly from multidimensional aspects may result in a variety of input pertaining to their housing need. Therefore, this outlines the importance of assessing the current neighbourhood environments and allow for a proper plan for the housing needs of future older persons to be considered (Alley et al., 2007).

A few studies had been conducted on the topic of the ageing population housing (Ferreira, 2013; Lipman et al., 2012; Wardrip, 2010; Stimson \& McCrea, 2004). Housing situation varies according to countries (Iwarsson et al., 2006), suggesting that each country should determine its own housing needs especially for the elderly. For example, in Hong Kong where land is scarcely available, most of its population live in the vertical residential building. Contrastingly, the ageing population in Malaysia seems to have a variety of type of housing, where some of them occupy the kampong house, some occupy the terrace house, some live in the semi-detached or detached house, and some do live in the vertical residential building. This factor influences the difference in terms of the housing needs in different countries. Needs are related to health status and lifestyle changes, whereas wants are rooted in cultural, social, and economic issues related to lifestyle changes (Lee et al., 2004).

In addition, the internal and external conditions of the elderly house are a good predictor of physical and psychological wellbeing of older people. Internal dwelling components including interior illumination, temperature, ventilation, lift, and stairs exert significant influence on life satisfaction among the elderly (Phillips, 2005). It is known that ageing causes changes in physical appearance and body's functions which may include reduced vision, body imbalance as well as weak muscle. Lim et al. (2014) found that were common cases of home injury among elderly people in Malaysia due to falls, cuts and struck by objects. These injuries happened mostly in the kitchen, bathrooms and garden.

A number of research (Robinson, 2012; Rosnah et al., 2008; Demirkan, 2007) suggested that the elderly population mainly experience risks and problems since they occupy old houses and neighbourhoods, which can threaten their mobility, comfort as well as their safety. Their house may now be an empty-nest and thus, may be too large in contrast to their current needs, and they are more likely to be in physical disrepair and suffer from other common defects such as water leakage, inefficient lightning and electrical and other flaws (Golant, 2008). Take the example of a 60year old elderly, who had inherited the house from his parents and had been living in the same house since the day he was born. Surely, in this context, we are able to deduce that the house requires more detail housing maintenance and up-keeping from its sickly owner. In this situation, we can conclude that, the ageing population needs housing that will not only facilitate their mobility and comfort, but is also safe for them.

Becoming the elder-friendly communities require not only to address the needs of the current older population, but also planning for the needs of the future older residents (Alley et al., 2007). This implicates that not only it is important to assess the current ageing population's housing needs, but it is also essential to plan for the future needs of the future ageing population. This is the underpinning reason why in this study, the respondent's age targets at those who were considered young-elderly aged 40 years old rather than focusing on those above 60 years old. Previous studies on ageing population housing were mainly focused on senior housing, sheltered housing, nursing houses and 
community dwellings rather than private housing (Smets, 2012; Demirkan, 2007). Therefore, this study fills the study gap and was conducted with the aim to determine the housing preference amongst the targeted groups.

\subsection{Elderly housing options in Malaysia}

There are several options of living arrangements for the elderly in Malaysia. The institution supports are provided by the Department of Social Welfare which is given a specific funding by the Federal Government. Amongst the residential care centre established under this department are Rumah Seri Kenangan and Rumah Ehsan. There are currently nine (9) Rumah Seri Kenangan across Malaysia that provide caring facilities for the elderly poor who live alone, unable to support themselves, have no contagious diseases and physically independent. The centre provides services such as medical care, counselling, and physiotherapy, spiritual and also recreational facilities. Rumah Ehsan, on the other hand, is established to provide comfortable care facilities, treatment and shelter for those who are chronically ill and unable to support themselves in terms of their physical and monetary needs (Akil et al., 2013). Another form of support from the government is the Senior Citizen Activity Centre (PAWE), which is a daily activity centre, where the elderly are sent to the centre, and their activities are monitored by the full-time staff or nurse. The Ministry of Women, Family and Community Development has developed the activity centres for the elderly in all the states in Malaysia, and the centre's activities are purposely designed to encourage social interaction with society.

Apart from public residential homes, the services and facilities for the elderly are also given attention by the private sector, nongovernmental Organisations (NGOs), charitable organisation and religious bodies with the aim to provide a better programme, services, and accommodation for the elderly (Ismail, 2014; Akil et al., 2013; Sulaiman et al., 2006). These private residential homes are mostly operated based on a charity basis.

Due to increasing demand for quality retirement living options, a few developers have beginning to experiment with the concept of the retirement village in Malaysia. A retirement village is a cluster of privately-owned residences for those above the aged of 55 years and are relatively in good health and able to live independently. These projects commonly incorporate a range of facilities and social and recreational activities, and some now make provision for people from a wider age range including those still in employment. Flexible care is typically available, including home help, personal care, health care, home maintenance, catering facilities and transport. The retirement village also includes on-site aged care facility to cater for those who are less mobile and independent.

Uniquely in Malaysia, several religious retirement homes have been operated by religious organisations. Also known as "Pondok" or "Madrasah", the establishment concerns inclu incorporating educational and spiritual elements into the residential activities and facilities for the elderly (Ismail, 2014). Baitul Maab in Temerloh (East Malaysia) for example provides two tenure options to the residents. They can either rent at RM100 per month inclusive of utility or own (waqf) with a purchase price from RM20,000 per unit. Residents must be aged 45 and over and are Muslims in order to be able to purchase a unit in Baitul Maab. Residents must be independent and healthy and do not have any chronic illnesses that require assistance. The main differences between Baitul Maab and other retirement accommodation is that the residents, upon application must be willing to participate in the life-long education program including fardu ain (religious) classes and other religious practices and programme (Hanif, 2016).

Nevertheless, ageing in their present place became the preferred option for the many independent elderly including Malaysia, as they prefer to remain in the existing communities rather than move to a new community though that option may physically be suited to their needs (Aini et al., 2016; Ball, 2012). This option is preferred due to a sense of attachment or connection and feelings of security and familiarity in relation to both homes and communities (Wiles et al., 2011). The elderly develops a sense of place through the aesthetic and usability of the environment even though the elderly are not in familiar places. Aging in place is also associated with the cultural and belief value. In general, the majority of Malaysians practice filial piety, where the younger generation was taught to respect and care for the older generation (Sim, 2001). Phillips et al. (2011) stated the relationship between the elderly and their environment; the elderly are generally satisfied with their living environment which makes them feel the sense 
of attachment and comfort in their current living area.

\subsection{Housing policy for the elderly in Malaysia}

Currently, Malaysia's lack of standardization and guidance in the practice of housing for the elderly is apparent. The provision of the housing for the elderly in Malaysia is not considered as part of the mainstream housing programme. The policies in the context of housing for the elderly in Malaysia are fragmented in terms of the governance division. There is a division in terms of governance pertaining to this matter, which demonstrates the discrepancies between authorities managing the issues of housing for the elderly. The matters of housing in Malaysia are under the jurisdiction of the Ministry of Wellbeing, Housing and Local Government, whereas the affairs of the elderly are under the responsibility of the Ministry of Women, Family and Community Development. Furthermore, at the state level, the elderly matters are operated by the Department of Social Welfare. Based on these divisions of governance, the issues related to housing and the elderly are quite challenging to be coordinated. The shortfall arising from this issue contributes to the mismanagement of housing for the elderly and is significantly challenging in terms of implementation.

The housing policies for the elderly in Malaysia are mostly confined within the social provision and service for the elderly. Other policies relating to the elderly are confined to health matters since it is considered as a major issue for the elderly. This encompasses the provision of affordable health care, better financial security, a chance for working and most important, a suitable housing and living environment for them. The division on the housing needs of the elderly are included under those who are in need and are entitled to apply for the affordable housing scheme. A related policies regarding elderly are highlighted in the National Housing Policy (NHP) Thrust 1; under the provision of adequate housing based on the specific needs of the target groups areas are provided as follows: Since housing is considered an essential need for humans, the government is making an effort to provide affordable housing for the target groups who who cannot afford to purchase a house and are disabled, which include the elderly community.

The policy is mainly aimed at the elderly community together with those who are not able to financially support themselves, together with disabled people, orphans, and single mothers. There was an initiative carried out by The Town and Country Planning Department (JPBD) to create a standard plan and guideline for the development of shelter facilities for the elderly which is still in deliberation by the authorities at the draft improvement stage. The provision of housing for the elderly in Malaysia is under the jurisdiction of the Social Welfare Department (Akil et al., 2013), where they focus on taking care of the elderly who meet certain criteria such as age 60 years old and above, have no permanent place to stay, no family members and relatives and able to abide by the rules and regulations established by the respective authorities.

\section{METHODOLOGY}

Middle adults Malaysian aged 40 and above living in urban areas of Greater Kuala Lumpur were selected as respondents. Studying younger cohorts and those nearing the retirement age has been propounded in similar research related to housing expectations of their elderly life in other countries. Ngee Ann Polytechnic (2011) and Costa-Font et al. (2009) for example looked into the age 40 and above in their housing preference for retirement research. Studying a younger elderly cohort has been argued to be important as Malaysia is currently encountering rapid changes in the demographic transition (Hamid, 2015). As such, there is an urgency to prepare the nation for the eventuality as it takes more than a decade for social institutions to change.

Face-to-face surveys were carried out on 464 eligible respondents between January and June 2014 across Kuala Lumpur. The average time taken to complete the face-to-face survey was about 40 minutes. The enumerators were also assigned based on ethnicity quotas to ensure that the study population would reflect the demographic characteristics of the area. This technique allowed enumerators to explain and clarify the questions especially to the respondents who had low literacy rates. This technique also proved to be more helpful for older respondents who had hearing impairment. The respondents were asked to rate their satisfaction level on their current house and neighborhood using a 5-point Likert scale, from 1 (not all satisfied) to 5 (Highly Satisfied).

\section{FINDINGS}

\section{Characteristics of respondents}


Table 2 summarises the age distribution of the respondents in this study. The majority of the respondents are Malay (60.1\%), followed by Chinese (30.2\%), and Indian (6.3\%). The respondents also have varied educational background. Two third of the respondent have tertiary level of education. About a quarter of them went to secondary school and only a small percentage did not obtain any formal education. The majority of the respondents are married $(80 \%)$ and only $11 \%$ are widows or widowers. On the other hand, less than $10 \%$ currently live alone and only a small group are divorcees.

Table 2 Age group of respondents

\begin{tabular}{ll}
\hline Age Group (years) & Respondents (\%) \\
\hline $40-49$ & 43.1 \\
$50-59$ & 34.3 \\
$60+$ & 22.6 \\
Total & 100.0 \\
\hline
\end{tabular}

About half of the respondents were working full-time in the private sector. In general, the respondents are from the middle income bracket as they report a monthly household income of between RM3, 000-RM10, 000 (Figure 1). The survey also reveals that most of the retired respondents receive a pension every month followed by a small percentage $(15.3 \%)$ of them who obtain a side income from net rental. About $11 \%$ of them receive a side income from their business and passive investments. In the context of their health condition, the majority claim they are healthy (84\%) while $16 \%$ of them are currently diagnosed with an illness.

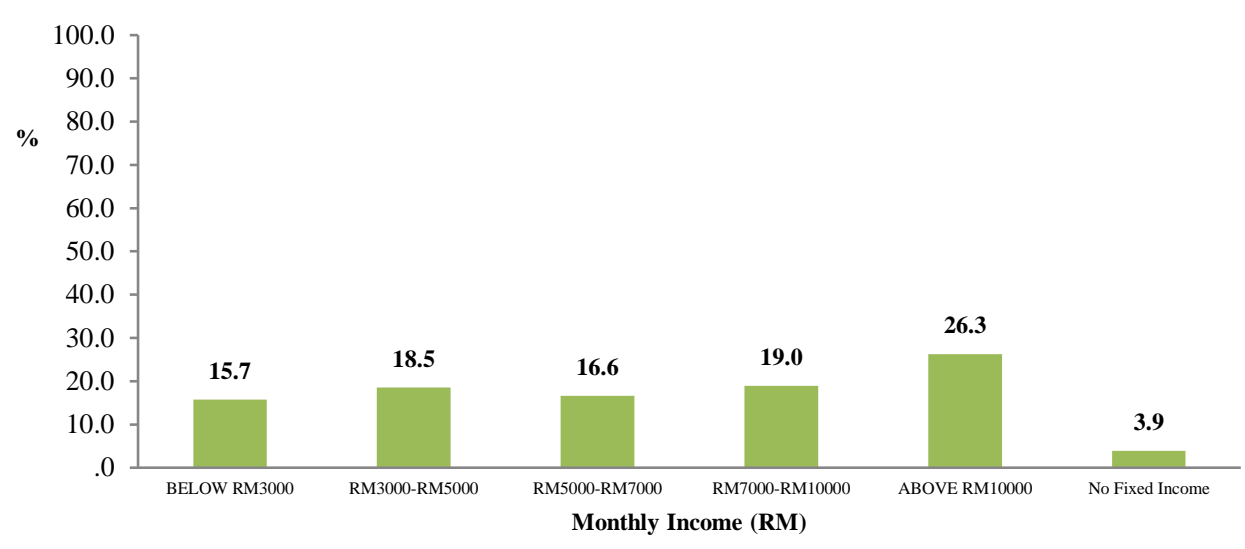

Figure 1 Household Monthly Income

\section{The current housing situation}

Table 3 summarises the selected demographic characteristics of the respondents. Most of the respondents lived in a double storey landed self-owned house. The majority $(69.8 \%)$ are homeowners, either sole owners or co-owned the house with their spouses. Only a small percentage $(8.4 \%)$ of the respondents is renting, and $3 \%$ stay with their children. This shows that majority of the urban middle adults living arrangement are secured. As they grow older, the children no longer live with them as the results reveal that more than a quarter of them either live alone or with their spouse. When the respondents were asked about the duration they have been residing in their current house, the majority feel attached to their current living environment. $65.5 \%$ of them have not moved from their current home for the past ten (10) years. Remaining in the same house has an added advantage of having a sense of attachment or connection and the feeling of security and familiarity both in terms of homes and community (Wiles et al., 2011)

Table 3 Selected Housing Characteristics of the respondents ( $N=464)$

\begin{tabular}{lcccc}
\hline & \multicolumn{3}{c}{ Age Group (\%) } & Average (\%) \\
\cline { 2 - 3 } & & $40-49$ & $50-59$ & $60+$ \\
$\begin{array}{c}\text { Type of House } \\
\text { Single Storey Terrace }\end{array}$ & 9.0 & 18.9 & 22.9 & 16.9
\end{tabular}


Double Storey Terrace

Single Storey Bungalow

Double Storey Bungalow

Flat (Low-Cost)

Apartment

Condominium

Double Storey Semi-Detached

Traditional House

Town House

Others

\section{Living Arrangement \\ Alone \\ Spouse Only \\ Children Only \\ Spouse And Children \\ Spouse + Children + Others \\ Others}

\section{Housing Status}

Own or co-own (with spouse)

Own by spouse/partner

Daughter/son

Relatives

Renting

Quarters

Others

3-10 years

11-20 years

More than 20 years

\begin{tabular}{|c|c|c|c|}
\hline 42.0 & 44.7 & 38.1 & 41.6 \\
\hline 2.5 & 6.3 & 4.8 & 4.5 \\
\hline 7.5 & 8.2 & 7.6 & 7.8 \\
\hline 6.0 & 5.7 & 12.4 & 8.0 \\
\hline 13.0 & 4.4 & 3.8 & 7.1 \\
\hline 13.0 & 5.7 & 2.9 & 7.2 \\
\hline 1.0 & 1.3 & 3.8 & 2.0 \\
\hline 1.0 & 2.5 & 1.9 & 1.8 \\
\hline 2.5 & 1.3 & 0.0 & 1.3 \\
\hline 2.5 & 1.3 & 1.9 & 1.9 \\
\hline 100.0 & 100.0 & 100.0 & \\
\hline 5.0 & 5.0 & 6.7 & 5.6 \\
\hline 5.5 & 12.6 & 20.0 & 12.7 \\
\hline 3.0 & 8.8 & 11.4 & 7.7 \\
\hline 65.5 & 42.8 & 39.0 & 49.1 \\
\hline 14.5 & 19.5 & 4.8 & 12.9 \\
\hline 6.5 & 11.3 & 18.10 & 12.0 \\
\hline 100.0 & 100.0 & 100.0 & \\
\hline 64.5 & 73.6 & 71.4 & 69.8 \\
\hline 13.5 & 14.5 & 9.5 & 12.5 \\
\hline 0.5 & 3.1 & 7.6 & 3.8 \\
\hline 1.5 & .6 & 1.9 & 1.3 \\
\hline 11.0 & 5.7 & 7.6 & 8.1 \\
\hline 4.0 & 1.3 & 1.0 & 2.1 \\
\hline 5.0 & 1.3 & 1.0 & 2.4 \\
\hline 100.0 & 100.0 & 100.0 & \\
\hline 44.0 & 20.8 & 31 & 32 \\
\hline 42.5 & 49.1 & 43.8 & 45.1 \\
\hline 6.5 & 29.6 & 21.8 & 19.3 \\
\hline 100 & 100 & 100 & \\
\hline
\end{tabular}

\section{Housing Satisfaction}

Housing satisfaction is highly associated with living options. The elements of perception act as a significant role in the individual conception of a home. In relation to the elderly community, the current home acts a domain aspect of their life, as it is associated with the physical, social and psychological well-being of the elderly. The respondents were asked in terms of physical safety as well as adequateness of size aspects pertaining to their housing components in their current dwelling. As Rosnah et al. (2008) highlighted, the elderly are exposed to accidents, primarily in their own homes as their conditions and mobility is degrading.

It can be seen from Table 4 that the respondents report that they feel satisfied with the safety aspect of all the areas in the house. Satisfaction with the safety of the living area and bedroom are the highest items with the mean score of $m=3.76$. The item with the lowest scores is the safety of bathroom. Some of the respondents raise concerns over the safety of the bathroom for their elderly living. They strongly express their concerns regarding their existing housing components particularly the bathroom areas. The respondents were also asked about the adequacy of the size of the residence for elderly living. The majority are satisfied with the current sizes for all the accommodation spaces in the house. The item that score the highest in the mean scores are the entrance $(m=3.68)$ while the lowest mean recorded is the bathroom $(\mathrm{m}=3.48)$. Based on the findings, it demonstrated that respondents feel less content with their bathrooms in both aspects (physical safety and adequateness of size) compared to the other housing components. Their concern is valid as the number of research have highlighted that a bathroom is a high risk area at home for falls or injuries to take place (Joshi \& Dsouza, 2015; Hjalmarson, 2014; Rosen et al., 2013). This suggests that the elderly require an improved technical bathroom design for them to move around safely. 
Table 4 Correspondence table on the satisfaction level of the current dwelling

\begin{tabular}{|c|c|c|c|c|c|c|c|}
\hline \multirow[b]{3}{*}{ Aspects } & \multirow[b]{3}{*}{ Sections } & \multicolumn{5}{|c|}{$\%$} & \multirow[b]{3}{*}{ Mean } \\
\hline & & 1 & 2 & 3 & 4 & 5 & \\
\hline & & $\begin{array}{c}\text { Not all } \\
\text { Satisfied }\end{array}$ & Unsatisfied & Neutral & Satisfied & $\begin{array}{c}\text { Highly } \\
\text { Satisfied }\end{array}$ & \\
\hline \multirow{9}{*}{ Safety } & Entrance & .6 & 3.2 & 28.4 & 57.5 & 10.1 & 3.73 \\
\hline & Living area & 6 & 2.6 & 28.0 & 57.3 & 11.4 & 3.76 \\
\hline & Dining area & .9 & 3.4 & 27.8 & 56.5 & 11.4 & 3.74 \\
\hline & Passageway & .6 & 6.3 & 31.9 & 51.9 & 9.3 & 3.63 \\
\hline & Bedroom & .6 & 2.8 & 28.0 & 56.7 & 11.9 & 3.76 \\
\hline & Bathroom & 1.5 & 10.6 & 26.5 & 51.1 & 10.3 & 3.58 \\
\hline & Kitchen & .6 & 10.3 & 26.9 & 51.5 & 10.6 & 3.61 \\
\hline & Compound & 1.1 & 9.0 & 28.5 & 51.3 & 10.1 & 3.60 \\
\hline & Staircases & 2.3 & 9.4 & 24.2 & 52.3 & 11.7 & 3.62 \\
\hline \multirow{9}{*}{ Size } & Entrance & .9 & 4.1 & 30.8 & 54.7 & 9.5 & 3.68 \\
\hline & Living area & 1.1 & 7.5 & 29.3 & 52.4 & 9.7 & 3.62 \\
\hline & Dining area & 1.1 & 8.2 & 27.8 & 53.2 & 9.7 & 3.62 \\
\hline & Passageway & .6 & 10.3 & 27.6 & 51.7 & 9.7 & 3.59 \\
\hline & Bedroom & .9 & 13.4 & 25.4 & 51.1 & 9.3 & 3.55 \\
\hline & Bathroom & 1.5 & 16.6 & 23.5 & 49.4 & 9.1 & 3.48 \\
\hline & Kitchen & 1.7 & 15.5 & 23.5 & 49.8 & 9.5 & 3.50 \\
\hline & Compound & 2.0 & 11.5 & 24.8 & 50.7 & 11.0 & 3.57 \\
\hline & Staircases & 3.9 & 8.2 & 18.4 & 57.0 & 12.5 & 3.66 \\
\hline
\end{tabular}

The respondents were asked to rate whether they require further renovation or extension in the future by using 5 -point Likert-scale, from 1 (don't need it at all) to 5 (really need it). Although they are generally satisfied with the physical safety and size of the current dwelling, some realised they needed to carry out building modifications to make it easier for them to continue living in their current home. The most needed modification were the renovation of the bathroom and kitchen area (Table 5). They further commented that they require non-slip flooring in both bathroom and kitchen area. The expectation (urgency) to renovate the bathroom rose steadily with increasing age. This suggests that as they grow older, they expect deterioration in their mobility around the house and fear of falling.

Table 3 Areas where renovation and extension are required

\begin{tabular}{lcccccc}
\hline \multicolumn{1}{c}{ Area } & $\begin{array}{c}\text { Don't need at } \\
\text { all }\end{array}$ & $\begin{array}{c}\text { Unlikely } \\
\text { need it }\end{array}$ & Neutral & $\begin{array}{c}\text { Maybe } \\
\text { need it }\end{array}$ & $\begin{array}{c}\text { Really } \\
\text { need it }\end{array}$ & Mean \\
\hline Bathroom & 14.4 & 18.1 & 23.7 & 34.3 & 9.5 & 3.06 \\
Kitchen & 15.5 & 15.9 & 26.9 & 31.9 & 9.7 & 3.04 \\
Bedroom & 15.3 & 20.7 & 29.5 & 26.1 & 8.4 & 2.92 \\
Dining area & 16.4 & 20.3 & 31.3 & 26.1 & 6 & 2.85 \\
Compound & 16.6 & 17.7 & 34.6 & 25.6 & 5.4 & 2.85 \\
Living area & 16.8 & 20.7 & 31.5 & 24.8 & 6.3 & 2.83 \\
Passageway & 16.4 & 24.8 & 38.6 & 16.2 & 4.1 & 2.67 \\
Staircases & 21.1 & 25.4 & 32.4 & 17.6 & 3.5 & 2.57 \\
Entrance & 20.5 & 25 & 36.4 & 14.2 & 3.9 & 2.56 \\
\hline
\end{tabular}


Table 6 summarises the satisfaction level regarding all the other housing components. On average, the respondents opined that they are satisfied and felt impartial towards any improvement rlated to the stated housing components. It indicates that the respondents are quite satisfied with their current house and do not required any major home modification for their later life. Based on the mean score, the aspect of 'layout design' is ranked highest compared to the other components $(\mathrm{m}=3.09)$. The requirement for improvement in terms of the number of rooms is ranked the lowest mean in the finding $(\mathrm{m}=2.86)$. Details of this analysis are as follows:

Table 4 Satisfaction on other housing components

\begin{tabular}{|c|c|c|c|c|c|c|}
\hline \multirow[t]{3}{*}{ Aspects } & \multicolumn{5}{|c|}{$\%$} & \multirow[t]{3}{*}{ Mean } \\
\hline & 1 & 2 & 3 & 4 & 5 & \\
\hline & $\begin{array}{l}\text { Don't need } \\
\text { at all }\end{array}$ & $\begin{array}{c}\text { Unlikely } \\
\text { need it }\end{array}$ & Neutral & $\begin{array}{c}\text { Maybe need } \\
\text { it } \\
\end{array}$ & $\begin{array}{c}\text { Really need } \\
\text { it }\end{array}$ & \\
\hline Layout design & 9.5 & 12.5 & 44.2 & 26.9 & 6.9 & 3.09 \\
\hline Lighting \& Shading & 12.5 & 17.9 & 38.8 & 27.2 & 3.7 & 2.92 \\
\hline Floor finishes & 15.7 & 16.6 & 36.9 & 24.6 & 6.3 & 2.89 \\
\hline $\begin{array}{l}\text { Access between } \\
\text { spaces }\end{array}$ & 12.1 & 17 & 45.9 & 21.8 & 3.2 & 2.87 \\
\hline No of rooms & 16.4 & 17.2 & 35.1 & 26.5 & 4.7 & 2.86 \\
\hline
\end{tabular}

In addition, respondents were also asked about the important aspects of living which contribute to a better house and environment for them, especially as they reach the age of retirement. The aspect of security $(m=4.27)$ and safety (4.19) are considered important for respondents and the mean are high for both aspects. Another significant finding is that the majority of the respondents agreed that affordable living cost are important in contributing to better house and environment for them (mean $=4.12$ ). However, the respondents' opinions are neutral regarding the level of importance inaspects such as specific design for the elderly $(m=3.87)$,

function layout and design of the unit $(\mathrm{m}=3.86)$, easy access to parts of the house as well as having great recreational amenities $(m=3.78)$. The majority of them opine that aspects of aesthetic values are less important for ageing people where the mean is 3.53. The findings shed significant indications on the housing needs of the elderly which are useful to formulate better planning and implementation policies for them in the future. Table 7 further shows the opinion on current housing in respect of the important aspects of their living conditions:

Table 5 Opinion on current housing (important aspect of living)

\begin{tabular}{|c|c|c|c|c|c|c|}
\hline & \multicolumn{5}{|c|}{$\%$} & \multirow[t]{2}{*}{ Mean } \\
\hline & $\begin{array}{c}1 \\
\text { not important at } \\
\text { all }\end{array}$ & $\begin{array}{c}2 \\
\text { less } \\
\text { important }\end{array}$ & $\begin{array}{c}3 \\
\text { neutral }\end{array}$ & $\begin{array}{c}4 \\
\text { important }\end{array}$ & $\begin{array}{c}5 \\
\text { very } \\
\text { important } \\
\end{array}$ & \\
\hline Safety and security & 0.4 & 0.4 & 12.9 & 44.6 & 41.6 & 4.27 \\
\hline Health & 0.4 & 0.6 & 14.2 & 48.7 & 36 & 4.19 \\
\hline Affordable living cost & 1.5 & 1.3 & 24.6 & 29.3 & 43.3 & 4.12 \\
\hline Specific design for elderly & 1.1 & 2.8 & 31 & 38.4 & 26.7 & 3.87 \\
\hline Layout and design & 1.3 & 3.4 & 24.6 & 49.8 & 20.9 & 3.86 \\
\hline Size & 2.4 & 5.4 & 19.8 & 50 & 22.4 & 3.85 \\
\hline Internal mobility & 1.1 & 1.9 & 32.8 & 46.3 & 17.9 & 3.78 \\
\hline $\begin{array}{l}\text { Recreational } \\
\text { amenities }\end{array}$ & 1.9 & 3.7 & 34.7 & 34.1 & 25.6 & 3.78 \\
\hline Aesthetic value & 2.6 & 6.5 & 41.4 & 34.3 & 15.3 & 3.53 \\
\hline
\end{tabular}

\section{Neighbourhood areas}

The study also evaluated respondents' opinion about the facilities provided in their neighbourhood using the scales of 1-5 which represent very good, good, average, poor and very poor. The findings (Table 8 ) show that the average readings for these three aspects: service facilities $(m=3.86)$, health facilities $(m=3.80)$ and leisure area $(\mathrm{m}=3.73)$. They argue that the services and provision of the abovementioned facilities can be improved as the readings 
indicate mix responses about it. Regarding public transportation services, most of the respondents agree that the local public transportation within their neighbourhood can be improved. The mean ranked is the lowest $(m=3.48)$. In respect of safety issues, more than half $(55 \%)$ of the respondents agreed that it is safe for them to walk alone during daytime. Nevertheless, almost half of them (43.1\%) confess that walking alone after dark within their neighbourhood is a slightly unsafe.

Table 8 Opinion about the facilities in their neighbourhood

\begin{tabular}{|c|c|c|c|c|c|c|}
\hline \multirow[t]{3}{*}{ Aspects } & \multicolumn{5}{|c|}{$\%$} & \multirow[t]{3}{*}{ Mean } \\
\hline & 1 & 2 & 3 & 4 & 5 & \\
\hline & Very poor & Poor & Average & Good & Very good & \\
\hline Social and leisure & .9 & 3.4 & 36.2 & 40.9 & 18.5 & 3.73 \\
\hline Facilities & 0 & 3.9 & 25.9 & 50.2 & 20.0 & 3.86 \\
\hline Health facilities & 0 & 3.0 & 32.1 & 46.3 & 18.5 & 3.80 \\
\hline Public transportation & 4.7 & 9.5 & 33.6 & 37.1 & 15.1 & 3.48 \\
\hline Walking area & 2.8 & 11.4 & 36.6 & 36.0 & 13.1 & 3.45 \\
\hline
\end{tabular}

As shown in Table 9, there are mixed responses with regards to issues around their neighbourhood environment which may impact their residential satisfaction level. It is essential to have a great environment because it will lead to better quality of life. The problems highlighted around the neighbourhood areas are mostly traffic congestion, crime, vandalism and pollution. Though they were satisfied, based on the mean rank result, they feel that several problems such as crime $(\mathrm{m}=3.06)$, the volume of traffic $(\mathrm{m}=3.09)$ and speed of traffic $(m=3.016)$ are of concerned as they get older.

Table 9 Neighbourhood concerns

\begin{tabular}{lcccccc}
\hline \multicolumn{1}{c}{ Problems } & \multicolumn{1}{c}{$\%$} & \multicolumn{3}{c}{ Mean } \\
& $\begin{array}{c}\text { Serious } \\
\text { problem }\end{array}$ & $\begin{array}{c}2 \\
\text { Problem }\end{array}$ & $\begin{array}{c}3 \\
\text { Uncertain }\end{array}$ & $\begin{array}{c}4 \\
\text { Minor } \\
\text { problem }\end{array}$ & $\begin{array}{c}5 \\
\text { Not a } \\
\text { problem }\end{array}$ & \\
\hline Animal's litters & 3.7 & 11.2 & 38.4 & 21.8 & 25 & 3.53 \\
Vandalism & 2.6 & 12.9 & 36.2 & 26.9 & 21.3 & 3.52 \\
Uneven pavement & 1.9 & 11.9 & 41.4 & 23.3 & 21.6 & 3.51 \\
Noise & 4.3 & 14.9 & 38.6 & 25.6 & 16.6 & 3.35 \\
Rubbish & 4.3 & 15.7 & 39.2 & 28.4 & 12.3 & 3.29 \\
Air quality & 3.7 & 17.2 & 43.8 & 23.7 & 11.6 & 3.22 \\
Speed of traffic & 8 & 24.8 & 22.2 & 33.4 & 11.6 & 3.16 \\
Volume of traffic & 9.3 & 25.2 & 22.6 & 32.8 & 10.1 & 3.09 \\
Crime rate & 5.4 & 25.9 & 33.4 & 28.4 & 6.9 & 3.06 \\
\hline
\end{tabular}

\section{Future plan for housing}

The majority $(68 \%)$ of the total respondents' desire to remain in the current housing. This implies that ageing in place is the most preferred for middle adults. About $22 \%$ of them are considering moving in the future (Figure 2) and they are mainly from the 40-49 age cohort. Table 10 shows that compared to the younger groups, the older cohort is less inclined to consider moving. This is consistent with previous research (See Ball, 2012; Phillips et al., 2011; Dekker et al., 2011, Parkes, Kearns and Atkinson, 2002) which suggest that the older we become, the more likely we are to be satisfied with the various dimensions of our residential environment. 


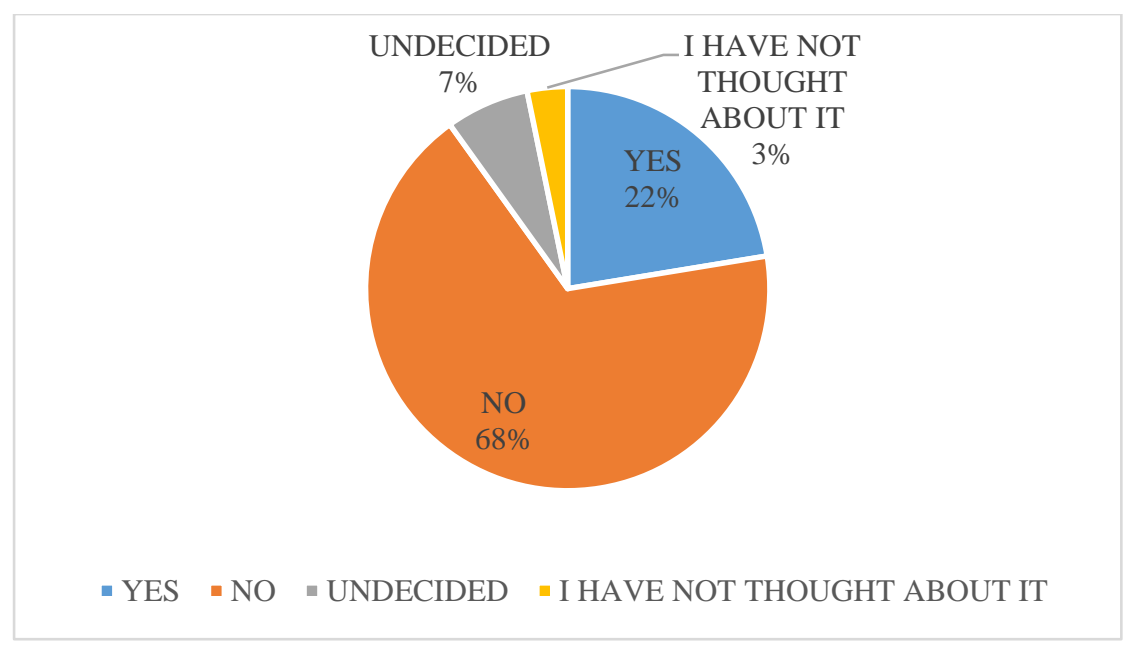

Figure 2 Intention of moving

Table 6 Moving intention by age group

\begin{tabular}{ccccc}
\hline & \multicolumn{3}{c}{ Age Group (\%) } & Average (\%) \\
& $40-49$ & $50-59$ & $60+$ & \\
\hline Yes & $34.5 \%$ & $11.9 \%$ & $15.2 \%$ & $20.6 \%$ \\
No & $53.5 \%$ & $78.0 \%$ & $79.0 \%$ & $70.2 \%$ \\
Undecided & $9.0 \%$ & $5.7 \%$ & $3.8 \%$ & $6.2 \%$ \\
I have not thought about it & $3.0 \%$ & $4.4 \%$ & $1.9 \%$ & $3.1 \%$ \\
& 100.0 & 100.0 & 100.0 & \\
\hline
\end{tabular}

The majority of the respondents who have the intention to move out in the future $(n=104)$ plan to purchase a new house $(70.10 \%)$. This is rather expected. Several options are given for the respondents to choose and amongst the options are the retirement village, madrasah or pondok which commonly incorporate a range of facilities and social and recreational activities. A few of these housing options for the elderly are further available to people from a wider age range including those still in employment. Only a small group of them intent to move into a retirement village in the future, the majority of whom are elderly. Surprisingly, some of the respondents show some interest to purchase specific accommodation for older people in the future. Some plan to rent out their current house rather than pass it to their children. When asked which type of housing would they consider if there is such a move, interestingly, about $18 \%$ from the total number of respondents have strong desire to purchase a single storey house. Houses such as a single storey bungalow and a traditional house also become the preferred choices for them. However, most of the respondents $(21.2 \%)$ chose double storey terrace houses to be purchased in the future (as shown in Figure 3). Interestingly, a few respondents choose to purchase high-rise building such as a condominium, apartment and flat as an alternative housing choice. 


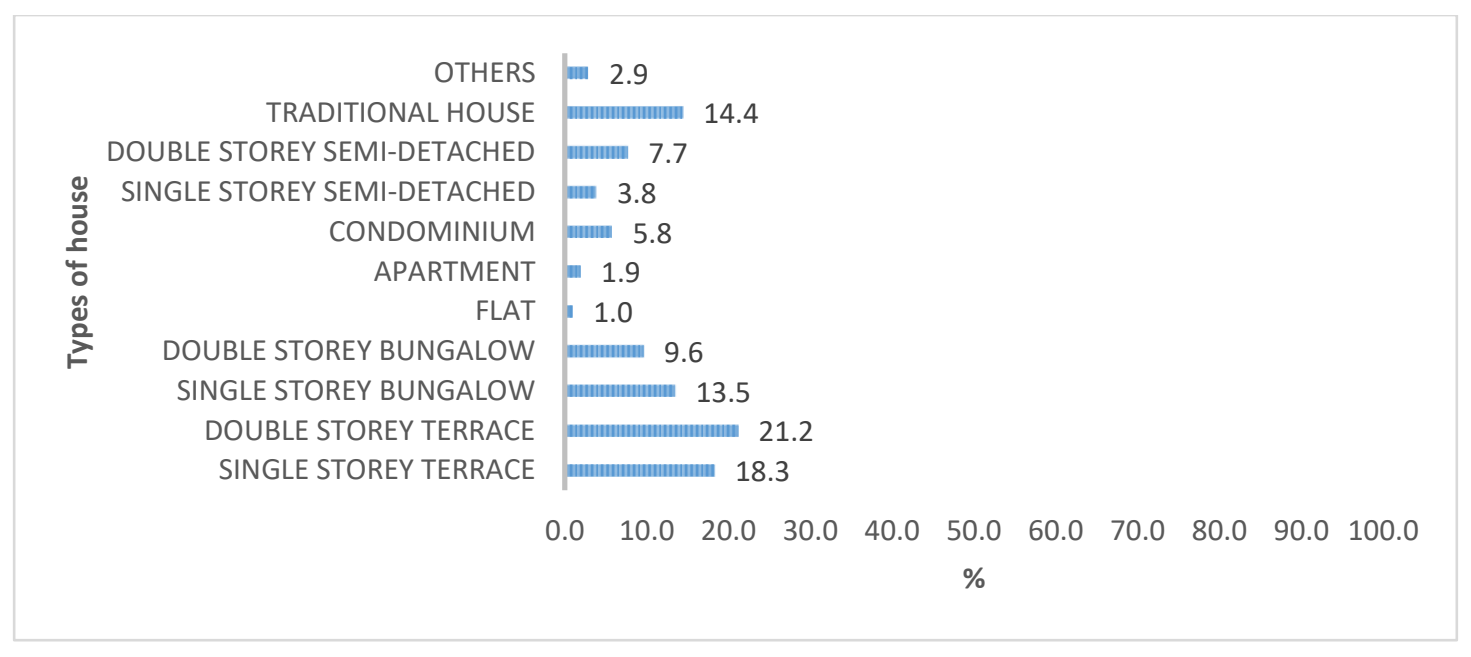

Figure 3 Future housing choices

In considering the location of purchasing a new house for the respondents who are willing to move, the majority of them strongly express the wish to stay in a different town, but within the same state $(40 \%)$, followed by $37.5 \%$ of them want to stay in the same town which they currently live in. Table 11 shows the future housing preferences by different age cohorts.

Table 11 Future housing preferences by age groups $(n=104)$

\begin{tabular}{|c|c|c|c|c|}
\hline & \multicolumn{3}{|c|}{ Age Group (\%) } & \multirow[t]{2}{*}{ Average (\%) } \\
\hline & $40-49$ & $50-59$ & $60+$ & \\
\hline \multicolumn{5}{|l|}{ Reason to move out } \\
\hline Buying new home & 84.1 & 68.4 & 62.5 & 71.7 \\
\hline Move in with relatives & 2.9 & 15.8 & 6.3 & 8.3 \\
\hline Renting & 4.3 & 0.0 & 0.0 & 1.43 \\
\hline Retirement village & 2.9 & 0.0 & 6.3 & 3.07 \\
\hline \multirow[t]{2}{*}{ Other } & 5.8 & 15.8 & 25.0 & 15.6 \\
\hline & 100.0 & 100.0 & 100.0 & \\
\hline \multicolumn{5}{|l|}{ Plan for current house } \\
\hline Sell the house & 11.6 & 15.8 & 6.2 & 11.2 \\
\hline Rent out & 37.7 & 26.3 & 31.2 & 31.7 \\
\hline Give to children & 15.9 & 31.6 & 31.2 & 26.2 \\
\hline Charity & 1.4 & 0.0 & 0.0 & 0.47 \\
\hline Can't make decision as this is not their house & 15.9 & 21.1 & 18.8 & 18.6 \\
\hline \multirow[t]{2}{*}{ Others } & 17.4 & 5.3 & 12.9 & 11.9 \\
\hline & 100.0 & 100.0 & 100.0 & \\
\hline \multicolumn{5}{|l|}{ Future housing choices } \\
\hline Single storey terrace & 14.5 & 26.3 & 25.0 & 21.9 \\
\hline Double storey terrace & 20.3 & 15.8 & 31.3 & 22.5 \\
\hline Single storey detached & 15.9 & 15.8 & 13.5 & 15.1 \\
\hline Double storey detached & 4.3 & 31.6 & 6.3 & 14.1 \\
\hline Flat & 1.4 & 0.0 & 0.0 & 0.5 \\
\hline Apartment & 2.9 & 0.0 & 0.0 & 0.97 \\
\hline Condominium & 7.2 & 0.0 & 6.3 & 4.5 \\
\hline Single storey semi-detached & 5.8 & 0.0 & 0.0 & 1.9 \\
\hline Double storey semi-detached & 11.6 & 0.0 & 0.0 & 3.87 \\
\hline
\end{tabular}




\begin{tabular}{lcccc}
\hline Traditional house & 11.6 & 10.5 & 31.3 & 17.8 \\
Others & 4.3 & 0.0 & 0.0 & 1.4 \\
\cline { 2 - 5 } & 100.0 & 100.0 & 100.0 & \\
\cline { 2 - 5 } Location for future house & & & & \\
Within the same location currently lived in & 40.6 & 26.3 & 37.5 & 34.8 \\
Different town but the same state & 42.0 & 36.8 & 31.3 & 36.7 \\
Other state & 17.4 & 36.8 & 31.3 & 28.5 \\
\cline { 2 - 5 } & 100.0 & 100.0 & 100.0 & \\
\hline
\end{tabular}

Their opinions regarding housing needs were also explored. Respondents were given the options based on he scale of 1-5 which were strongly disagree, disagree, neutral, agree and strongly agree. The findings (see Table 12) demonstrate that majority of them claim that it is indeed important for them to live close to friends and relatives $(50 \%)$ and they also highlight the importance of living close to their children (66.3\%). On average, most of the respondents made it clear that they do not need assistance from their children and relatives to go to any destination $(\mathrm{m}=3.01)$ According to the response, on the scale from strongly disagree to strongly agree, most respondent indicate that either they strongly disagree $(21.1 \%)$ or disagree (26.5\%) with the statement "I need support to clean my house", which indicated that they are still capable of doing chores at home.

Table 12 Opinion on future housing

\begin{tabular}{|c|c|c|c|c|c|c|}
\hline \multirow[t]{2}{*}{ Area } & \multirow[b]{2}{*}{$\begin{array}{l}\text { Strongly } \\
\text { disagree }\end{array}$} & \multicolumn{4}{|c|}{$\%$} & \multirow[t]{2}{*}{ Mean } \\
\hline & & disagree & neutral & agree & $\begin{array}{c}\text { strongly } \\
\text { agree }\end{array}$ & \\
\hline I need to live close to my children & 0.2 & 2.6 & 23.9 & 39.4 & 26.9 & 3.97 \\
\hline $\begin{array}{l}\text { I need to live close to good public } \\
\text { transportation system }\end{array}$ & 1.5 & 6.5 & 28 & 38.6 & 25.4 & 3.8 \\
\hline $\begin{array}{l}\text { I need to live close to my relatives } \\
\text { and friends }\end{array}$ & 1.1 & 8.2 & 44.6 & 34.1 & 12.1 & 3.48 \\
\hline I need support to clean my house & 3.2 & 21.1 & 37.9 & 26.5 & 11.2 & 3.21 \\
\hline $\begin{array}{l}\text { I need the support of my children } \\
\text { or my relatives to go to any } \\
\text { destination }\end{array}$ & 5 & 23.7 & 44.2 & 19.4 & 7.8 & 3.01 \\
\hline I need to live close to my children & 0.2 & 2.6 & 23.9 & 39.4 & 26.9 & 3.97 \\
\hline
\end{tabular}

\section{DISCUSSIONS}

The elderly population has become an emerging concern around the world and Malaysia is also expected to become an ageing country by the year 2030. It is estimated that population of people age 60 years and above will form 15\% of the total population in 2030. Thus, a research of this nature becomes a wakeup call for the nation, to prepare a suitable program or action plan in order to cater to the rising population of these silver lining tsunami. Various study (Ismail, 2014; Akil et al., 2013; Sulaiman et al., 2006) which focused on the elderly are recent and currently ongoing, and the housing sector has become one of the major aspects in determining the future needs of the aged population. Hence, this research was conducted to gain information on housing, and it will also become a database for preparing for a better housing accommodation for them. The findings indicated that different age groups have different views and perceptions related to future housing. A large majority of the respondents indicated strong desires to stay at their current houses. Even though most of them are comfortable in their homes, there is room for improvement pertaining to some housing components inside their houses. The outputs from this survey showed that some people living in flats need other appropriate dwelling units in order to attain satisfaction or comfort. Based on the interviews, changes are required with respect to floor materials, the number of rooms, renovation or extension for some of the housing components such as bathrooms and bedrooms. Surprisingly, the aspects of aesthetic value are less important for the respondents. 
The majority of the respondents agreed that affordable living cost is the most vital aspects of living, apart from having suitable facilities and environment.

A dominant percentage of the respondents are happy living in their current neighbourhood. The result also shows that most of the respondents are satisfied with the current provision of facilities in their residential area. Having good facilities around the neighbourhood lead to the contribution of a better quality of life and environment can be observed. Apart from that, in terms of safety, the majority of respondents are aware and taking precautions with their surroundings, by refraining from going out at night and by being extra careful while walking alone during the daytime. Despite having a good neighbourhood, problems do occur. Many of them by consensus agreed that crime is definitely a problem in their community. Other than that, traffic congestion and traffic volume were also identified as problems for the respondents.

Most of the respondents expressed a strong aspiration to continue to stay in their current house, and they are not familiar with the concepts of retirement village and madrasah as the elderly housing accommodation. Most of them do not aspire to move due to financial constraint and also due to the fact that they are not able eligible to apply for any housing loan because of their age. They also stated that they are satisfied with their current house. Despite all these, there are a group of people who were interested in the concept of purpose-built homes specifically for the elderly in a retirement village. Majority of the respondents who aged between 40 to 49 , and 60 years and above had considered moving to a retirement village, if there were such a concept in Malaysia. They stated that their main reason was they wanted to spend time with people who are of the same age and doing beneficial activities together. Currently, the provisions for the elderly accommodation in Malaysia are more geared towards welfare services such as old-folks home and nursing care centre. The admission of the elderly into these community centres sometimes invites a negative perception that their children do not wish to take care of their parents. This negative perception also causes a negative misunderstanding about the concept of a retirement village. Many viewed retirement village as a place to abandon elderly parents. Therefore, it creates various discernments regarding the future plan of housing.

\section{CONCLUSION}

In summary, the urban elderly in Greater Kuala Lumpur prefer to age at their current residence. Feeling contented generally, their dissatisfaction on certain apects of their current housing may require them to make adjustments to adapt to their future needs. Hence, a proper layout and design are essential for that improvement. The urban elderly also highlighted the importance of transportation and walking access to their facilities. However, the findings of this research are based on the current health and financial status of the respondents. Should the status changes, there is a possibility that the findings may no longer be valid.

Based on our findings, to a great extent, it is clearly suggested that the government should take more active action in addressing the needs of the ageing community. This could be accomplished through the development and implementation of an action plan to support ageing in their current place. It is recommended that the housing policies should be created in such a way that it enables the elderly to live independently as long as they wish and only advance to higher levels of care when they need and wish for it. For example, the government could introduce a programme that provides elderly financial assistance for Ageing in Place renovations to help them stay in their homes and maintain their independence. In addition, elderly-friendly facilities in residential townships in the future should be mandatory. Despite the elderly population growing at a rapid rate, Malaysia still have a few more years to become an ageing nation. Therefore, greater awareness and preparation are required to overcome the imminent challenge. A strong collaboration between the Government, industry providers, families and communities to overcome the elderly housing challenges and needs is also required.

\section{REFERENCES}

Akil, S. M. S., Abdullah, S., Ghani, S. A., \& Othman, K. (2013). Developing quality care facilities and programs for elderly. Global Journal of Sociology, 03(1), 1-8.

Ahmad, F., Mohd, I., Maidin, S. L., Zainol, R., \& Noor, N. M. (2013). Malaysian Developement Plan System: Issues and Problems, One Decade after Its Reform (2001-2011). Planning Malaysia: Journal of the Malaysian Institute of Planners, 11, 120.

Aini, A. M., Murni, N., \& Aziz, W. N. A. W. A. (2016). Housing Aspirations of the Elderly in Malaysia: A Comparison of Urban and 
Rural Areas. Journal of Design and Built Environment, 17(2).

Alley, D., Liebig, P., Pynoos, J., Banerjee, T., \& Choi, I. H. (2007). Creating elder-friendly communities: Preparations for an aging society. Journal of Gerontological Social Work, 49(1-2), 1-18

Ball, M. S. (2012). Aging in Place: A toolkit for local government. Washington D.C, United States of America.

Burby, R. J., \& Rohe, W. M. (1990). Providing for the Housing Needs of the Elderly. Journal of the American Planning Association, 56(3), 324-340. doi:10.1080/01944369008975776

Costa-Font, J., Elvira, D., and Mascarilla-Miro, O. (2009). 'Ageing in Place'? Exploring Elderly People's Housing Preferences in Spain, Urban Studies, 46(2), 295-316.

Dekker,K., deVos, S., Musterd, S. and van Kempen, R. (2011). Residential satisfaction in housing estates in European cities: a multi-level research approach. Housing Studies, 26(4), 479-499.

Demirkan, H. (2007). Housing for the aging population. European review of aging and physical activity, 4(1), 33-38.

Ferreira, M. (2013). Housing for older people globally What are best practice? An ILC Global Alliance Discussion Paper. United Kingdom

Golant, S. M. (2008). Commentary: irrational exuberance for the aging in place of vulnerable low-income older homeowners. Journal of Aging \& Social Policy,20(4), 379-397.

Hamid, T. A. (2015). Population Ageing in Malaysia: A Mosaic of Issues, Challenges and Prospects (First Edit). Serdang, Selangor: Penerbit Universiti Putra Malaysia.

Hanif, N.R.H. (2016) Homes for Active Ageing: A Case Study of Private ReligionBased Residential for Active Ageing in Malaysia. Paper presented to the Asia Pacific Network for Housing Research Conference (APNHR), Guangzhou, 16-19 December 2016.

Harding, E. (2008). Sustainable planning for housing in an ageing population - a guide for regional level strategies. London SE 7TJ

Hillcoat-Nallétamby, S., \& Ogg, J. (2013). Moving beyond "ageing in place": older people's dislikes about their home and neighbourhood environments as a motive for wishing to move. Ageing and Society, 1-26. doi:10.1017/S0144686X13000482

Hjalmarson, J. (2014). Ergonomics at Home Design for Safe Living and Home Care. Royal Institute of Technology, Stockholm.
Ismail, A. M. (2014). Retirement Village in Malaysia. Unpublished Master Dissertation, University of Malaya, Kuala Lumpur, Malaysia

Iwarsson, S., Nygren, C., Oswald, F., Wahl, H. W., \& Tomsone, S. (2006). Environmental barriers and housing accessibility problems over a one-year period in later life in three European countries. Journal of Housing for the Elderly, 20(3), 23-43.

Joshi, R., \& Dsouza, S. (2015). Bathroom hazards among older adults in western India: a cross-sectional study. Asian Journal Gerontology Geriatric, 10(2), 8391.

Kwon, H. J., Ahn, M., Lee, S.-J., \& Kim, S.-K. (2015). U.S. Baby Boomers' Desire to Age in Place and Residential Satisfaction. Journal of Housing for the Elderly, 29(4), 348-372.

https://doi.org/10.1080/02763893.2015.105 502

Lee, E., \& Gibler, K. M. (2004). Preferences for Korean seniors housing. Journal of Property Investment \& Finance, 22(1), 112-135.

Lim, K. H., Jasvindar, K., \& Normal, I. (2014). Risk factors of home injury among elderly people in Malaysia. Asian Journal of Gerontology \& Geriatrics,9, 16-20.

Lipman, B., Lubell, J., \& Salomon, E. (2012). Housing an aging population: Are we prepared? America. United State of America. Retrieved from http://www.nhc.org/about/Center-MissionGoals.html

Ng, S. T., Tey, N. P., Yew, S. Y., Sia, B. K., \& Long, B. S. (2012). Effects of Quality of Service and Activities on Life Satisfaction of Residents in Nursing Homes. Wulfenia Journal, 153-160.

Ngee Ann Polytechnic. (2011). Real Estate Needs of Senior Citizens: A Focus on Retirement Villages in Singapore. Singapore: Building \& Environment Division, Ngee Ann Polytechnic

Parkes, A., Kearns, A. and Atkinson, R. (2002). What makes people dissatisfied with their neighbourhoods? Urban Studies, 39(13), 2413-2438.

Phillips, J., Walford, N., \& Hockey, A. (2011). How do unfamiliar environments convey meaning to older people? Urban dimensions of placelessness and attachment. Inernational Journal of Agieng and Later Life, 6(2), 73-102.

Philips, D. R., Siu, O., Yeh, A. G. O., \& Cheng, K. H. C. (2005). The impacts of dwelling conditions on older persons' psychological well-being in Hong Kong: The mediating 
role of residential satisfaction. Social Science and Medicine, 60, 2785-2797.

Rioux, L., \& Werner, C. (2011). Residential satisfaction among aging people living in place. Journal of environmental psychology, 31(2), 158-169.

Robinson, H. (2012). A Guide for Making Housing Decisions- Housing Option for Older Adults. Washington D.C.

Rosen, T., Mack, K. A., \& Noonan, R. K. (2013). Slipping and tripping: fall injuries in adults associated with rugs and carpets. Journal Injury Violence, 5(1), 61-69.

Rosnah, M. Y., Sharifah Norazizan, S. A. R., Tengku Aizan, H., \& Hussain, M. R. (2008). Home living environment design and perceptions of safety of older Malaysians. Gerontechnology, 7(2), 1-5. doi:10.4017/gt.2008.07.02.138.

Sim, O. F. (2001). Ageing in Malaysia: National Policy And Future Direction. University of Malaya, Kuala Lumpur.

Smets, A. J. (2012). Housing the elderly: segregated in senior cities or integrated in urban society? Journal of Housing and the Built Environment,27(2), 225-239.

Stimson, R. J., \& McCrea, R. (2004). A pushpull framework for modelling the relocation of retirees to a retirement village: The Australian experience. Environment and Planning A, 36(8), 1451-1470. doi:10.1068/a36206

Sulaiman, N., Baldry, D., and Ruddock, L., (2006) Housing and social policy in Malaysia: provision for the elderly. In ERES, 13th Annual European Real Estate Society, 7-10 June 2006, Weiwar, Germany.
Statistics Department (2017) Population Quick Info. [Online]. Available at http://pqi.stats.gov.my/searchBI.php (accessed August 2017)

Tang, C. S. K., Wu, A. M. S., Yeung, D., \& Yan, E. (2009). Attitudes and intention toward old age home placement: A study of young adult, middle-aged, and older Chinese. Ageing International, 34(4), 237251. doi:10.1007/s12126-009-9047-2

Tanner, B., Tilse, C., \& De Jonge, D. (2008). Restoring and sustaining home: The impact of home modifications on the meaning of home for older people. Journal of Housing for the Elderly, 22(3), 195-215.

Wagner, S. L., Shubair, M. M., \& Michalos, A. C. (2010). Surveying older adults' opinions on housing: Recommendations for policy. Social indicators research,99(3), 405-412.

Wardrip, K. (2010, March). Strategies to Meet the Housing Needs of Older Adults. AARP Public Policy Institute, (38).

Wiles, J. L., Leibing, A., Guberman, N., Reeve, J., \& Allen, R. E. S. (2011). The Meaning of "Ageing in Place" to Older People. The Gerontologist. doi:10.1093/geront/gnr098

Windley, P. G. (2003). Causal Modeling in Elderly Housing Satisfaction Research: Heuristic Device or Analytic Technique. In International Conference on Methodologies in Housing Research. International Association of People-Environment Studies (IAPS) and European Network for Housing Research (ENHR). Stockholm, Sweden. 